\title{
37. 地球温暖化を考慮した伊勢湾における高潮予測
}

Prediction of Storm Surge in Ise Bay under Global Warming Condition

舒 岩*・三村信男**

Yan Shu, Nobuo Mimura

ABSTRACT: It is expected that global warming may generate stronger typhoons due to increased sea surface temperature in the ocean. If this effect acts together with sea-level rise, storm surge will be higher on the coasts, resulting in a significant increase in the flood risk. This study examined based on numerical simulation how the climate change and sea-level rise induced by global warming will modify the storm surge and resul tant damages, taking the Ise Bay area as a case study site, because it was severely impacted by the Ise Bay Typhoon in 1959. Intensification of typhoon has stronger effect to heighten the storm surges than sea-level rise. If the strength of typhoon increases by $20 \%$, the damage of storm surge on the Ise Bay area will be much larger compared with that of the Ise Bay Typhoon.

Keywords; Global Warming, climate change, storm surge

\section{1. はじめに}

近年, 地球温暖化による気候変動・海面上昇の影響が一層懸念されるようになっている. 中でも, 地球温 暖化によって強い台風の発生確率が増大するという予測結果も報告されている. 日本においては昭和 20 年代 から 30 年代にかけて頻発した高潮災害の経験から海岸防護対策を推進した結果, かってのような甚大な被害 は過去 30 年間以上抑えられてきた. しかし，2004 年には観測史上最大の 10 個の台風が上陸し，大きな高潮・ 高波被害を引き起こすなど, 新しい被害状況が発生しつつある. 台風の常襲地帯である日本にとって, 台風 の勢力増強・より大きな高潮の発生は大きな劦威になる. 高潮の被害を最小限に抑えるためは, 温暖化によ って変化した高潮の挙動の再検討が必要である（筒井ほか，1992；桐ほか，2004；土持ほか，2004）。

過去の高潮被害においては, 東京湾・伊勢湾・大阪湾の三大湾など, 太平洋側の内湾における被害が圧倒 的に大きかった. そこで本研究では, 過去に最も大きな被害が発生した伊勢湾に着目し, 伊勢湾での地球温 暖化の影響による高潮被害を, 数值シミュレーションによって検討することを目的とした.

\section{2. 台風と高潮}

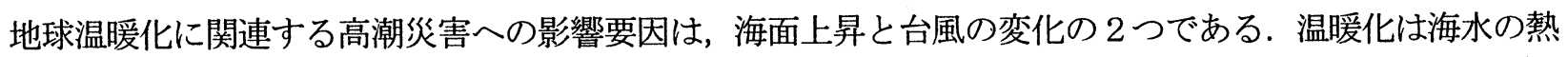
膨張と南極・大陸・グリーンランド皮床の減少, 山岳水河の融解を引き起こすために, 世界規模で海面が上 昇する. IPCC の第 3 次報告書では, 2100 年までに $9 \mathrm{~cm}$ から $88 \mathrm{~cm}$ の海面上昇が起こると予想されている (IPCC WGI, 2001). 一方, 発生後の台風の盛衰には台風進路にあたる海表面の水温が大きな影響を及ぼし, 海面水 温が上昇すると台風のエネルギ一源となる海水の蒸発が増大し, 台風の強度が増大すると考えられている.

*茨城大学大学院理工学研究科都市システム工学科専攻 Graduate School of Science and Technology, Dept. of Urban and Civil Engineering, Ibaraki University, **茨城大学広域水圈環境科学教育研究セン ター Center for Water Environment Studies, Ibaraki University 


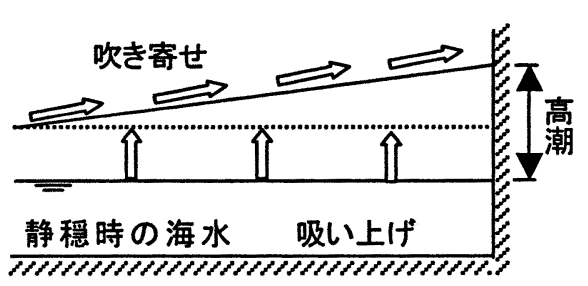

図 1 高潮のメカニズム

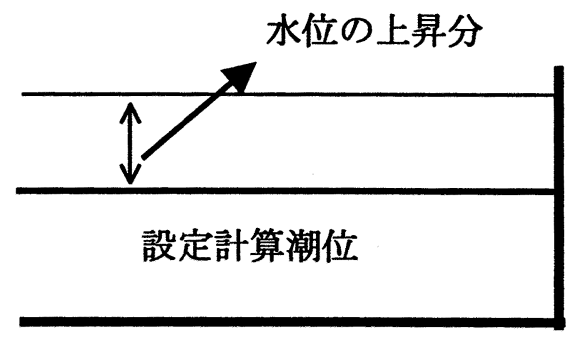

図 2 高潮潮位偏差の定義

\section{3. 高潮計算モデル}

高潮とは, 台風の接近に伴う強風や気圧の急変などが原因で, 海面の高さが平常より著しく高まる現象で あり, 発生要因には, 気圧低下による海面の吸い上げ効果と強風による海水の吹き寄せ効果の二つがある (図 1). また, 高潮潮位偏差は設定計算潮位からの水位の上昇分と定義される (図 2). 本研究では, 後藤・小川 （1982）および小島 (2001)の高潮計算モデルを用いて計算を行った. 高潮のように波長の長い波の運動は, 浅水長波理論によって表される. 本研究における高潮計算では, 水深の深い領域では線形長波理論を, 水深 の浅い領域では非線形長波理論を用いている.

\section{1 非線形長波理論による高潮の支配方程式}

$$
\begin{aligned}
& \frac{\partial \eta}{\partial t}+\frac{\partial}{\partial x}(u(h+\eta))+\frac{\partial}{\partial y}(v(h+\eta))=0 \\
& \frac{\partial M}{\partial t}+\frac{\partial}{\partial x}\left(\frac{M^{2}}{D}\right)+\frac{\partial}{\partial y}\left(\frac{M N}{D}\right)=f M-g D \frac{\partial \eta}{\partial x}-\frac{D}{\rho} \frac{\partial P_{0}}{\partial x}+\frac{1}{\rho}\left(\tau_{s x}-\tau_{b x}\right)+A_{h}\left(\frac{\partial^{2} M}{\partial x^{2}}+\frac{\partial^{2} M}{\partial y^{2}}\right) \cdots \\
& \frac{\partial N}{\partial t}+\frac{\partial}{\partial x}\left(\frac{M N}{D}\right)+\frac{\partial}{\partial y}\left(\frac{N^{2}}{D}\right)=f N-g D \frac{\partial \eta}{\partial y}-\frac{D}{\rho} \frac{\partial P_{0}}{\partial y}+\frac{1}{\rho}\left(\tau_{s y}-\tau_{b y}\right)+A_{h}\left(\frac{\partial^{2} N}{\partial x^{2}}+\frac{\partial^{2} N}{\partial y^{2}}\right) \cdots
\end{aligned}
$$

ここで, $M, N$ はそれぞれ $x, y$ 方向の流量, $u, v$ はそれぞれ $x, y$ 方向の流速, $\eta$ は水位, $h$ は静水深, $D$ は全 水深, $f$ はコリオリ係数 $\left(=2 \omega \sin \phi, \omega\right.$ : 地球自転の角速度, $\phi$ : 緯度), $p$ は圧力, $A_{h}$ は水平渦動粘性係数 である.

\section{2 線形長波理論による高潮の支配方程式}

$$
\begin{aligned}
& \frac{\partial \eta}{\partial t}+\frac{\partial M}{\partial x}+\frac{\partial N}{\partial y}=0 \quad \cdots(4) \\
& \frac{\partial M}{\partial t}=f M-g D \frac{\partial \eta}{\partial x}-\frac{D}{\rho} \frac{\partial P_{0}}{\partial x}+\frac{1}{\rho}\left(\tau_{s x}-\tau_{b x}\right)+A_{h}\left(\frac{\partial^{2} M}{\partial x^{2}}+\frac{\partial^{2} M}{\partial y^{2}}\right) \cdots(5) \\
& \frac{\partial N}{\partial t}=-f N-g D \frac{\partial \eta}{\partial y}-\frac{D}{\rho} \frac{\partial P_{0}}{\partial y}+\frac{1}{\rho}\left(\tau_{s y}-\tau_{b y}\right)+A_{h}\left(\frac{\partial^{2} N}{\partial x^{2}}+\frac{\partial^{2} N}{\partial y^{2}}\right) \cdots(6)
\end{aligned}
$$




\section{3 海上風の計算}

高潮推算に用いる海上風 (すなわち海面上 $10 \mathrm{~m}$ の風) は, 台風モデルにより推算した自由大気の風を, 海面 摩擦を考慮して変換するものである. そのため, 以下のような計算を行った.

a）傾度風モデル

気象図より得られる気象分布をもとに, 傾度風モデルを用いて推算する風は, 海面の摩擦の影響を受けな い自由大気の風を近似するものである。ただし, 気象図は地上の值を用…(7) とから, 正確には上空大気の 風ではないことに注意する。傾度風は，気圧傾度が与えられると以下の式(7)で計算できる.

$$
\mathrm{V}_{g r}=\frac{f R}{2}+\sqrt{\frac{f^{2} R^{2}}{4}+\frac{R}{\rho_{a}} \frac{\partial P}{\partial r}} \quad \cdots(7)
$$

ここで, $f$ はコリオリ係数, Rは等圧線の曲率半径, $\rho_{a}$ は空気密度である.

b）台風モデル

Myers の理論式(8)を用いた.

$$
P(r)=P_{c}+\Delta P \cdot \exp \left(-\frac{r_{0}}{r}\right)
$$

ここで, $P(r)$ は $r$ 地点における気圧, $r$ は台風中心からの距離, $P_{c}$ は台風中心の気圧, $\triangle P$ は台風の中心示 度, $r_{0}$ は台風半径である.

上述した二つのモデルによる海面摩擦の影響を受けない自由大気の風が計算される。高潮推算に用いら れる海上風へは, 傾度風速と場の風に 0.65 の風速低減率を乗じ, 低圧部に向けて風向を $30^{\circ}$ 偏向させるこ とにより変換した。

\section{4. 計算条件}

\section{1 解析領域}

高潮計算領域を図 3 に示寸. 大領域が北緯 33 度から 北緯 35.4 度まで, 東経 135 度から東経 137.6 度までであ り, 小領域が北緯 34.3 度から北緯 35.2 度まで, 東経 136.5 度から 137.2 度までである.

\section{2 モデル台風}

気候モデルによる推定では, 温暖化によって台風の規 模, すなわち最大到達強度(MPI) が 10\%〜20\%大きくな ることが知られている. 本研究では, 元になる台風を伊 勢湾台風とし,さらにMPI が 10\%および $20 \%$ 増大した三種 類の規模の台風を用いて計算を行った.

\section{3 評価地点と計算の設定潮位}

設定潮位による影響を解明するために, 対象海域の評価 地点として, 図 4 に示すように, 湾の入口 $(\mathrm{A}, \mathrm{H})$, 中央 $(\mathrm{B}, \mathrm{G}, \mathrm{F})$, 湾奥 $(\mathrm{C}, \mathrm{D}, \mathrm{E})$ の 8 つの地点を選んだ.

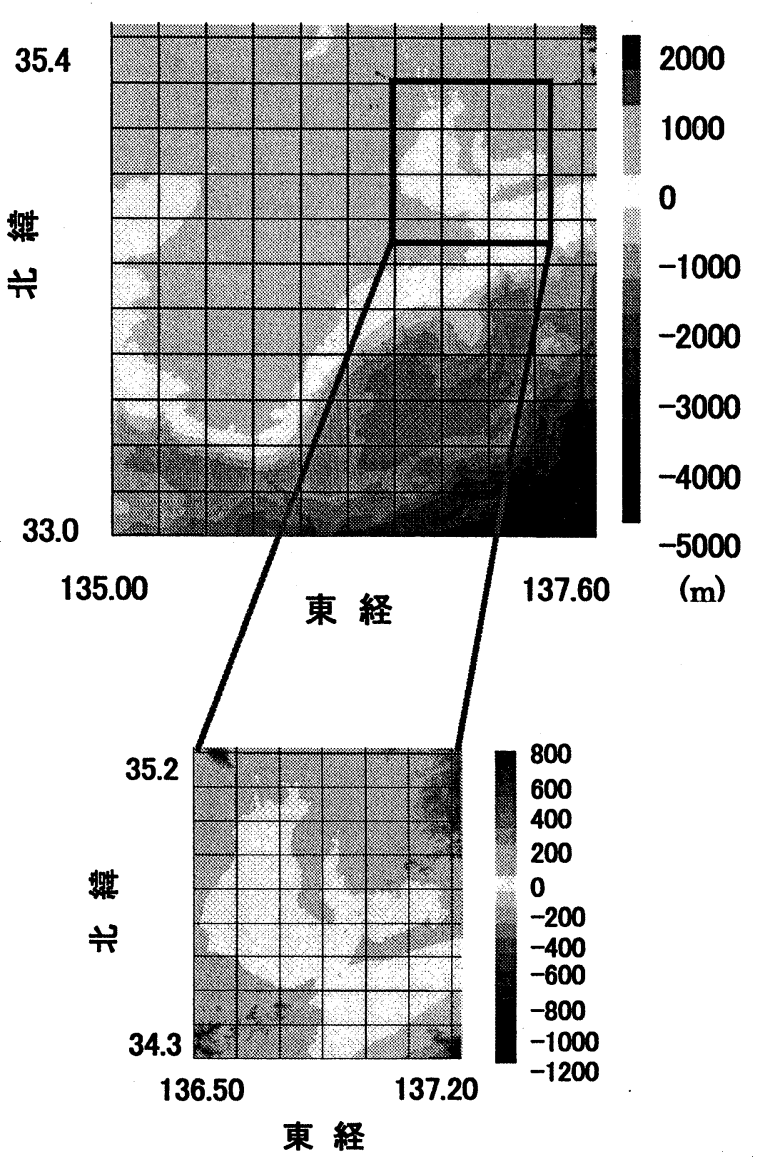

図 3 計算領域 


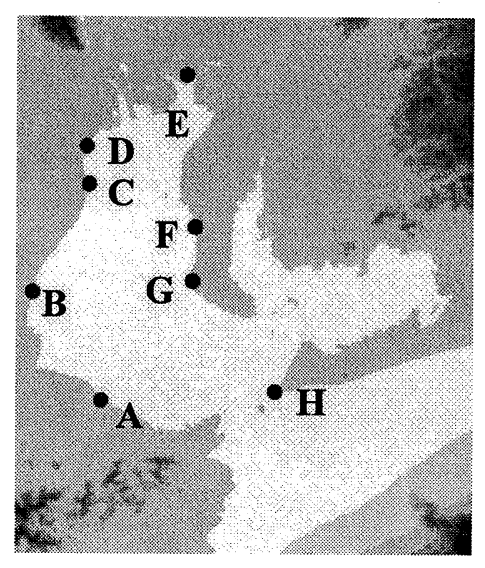

図 4 評価地点

表 1 計算設定潮位

\begin{tabular}{|c|c|c|}
\hline 計算潮位 & $\begin{array}{c}\text { 干潮位基準 } \\
\text { (m) }\end{array}$ & $\begin{array}{c}\text { 平均海面基準 } \\
\text { (m) }\end{array}$ \\
\hline 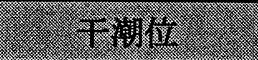 & $3 p=0.04$ & $\mathrm{TP}-1.37$ \\
\hline 海面止毕 $0.44 \mathrm{~m}$ & $\mathrm{NP}+0.48$ & $\mathrm{TP}=0.93$ \\
\hline 海面上早 $0.88 \mathrm{~m}$ & $\mathrm{NP}+0.92$ & $\mathrm{TP}=0.50$ \\
\hline 平均海面 & $\mathrm{NP}+1.40$ & TP-0.01 \\
\hline 海面上昇 $0.44 \mathrm{~m}$ & $\mathrm{NP}+1.84$ & $\mathrm{TP}+0.43$ \\
\hline 海面上昇 $0.88 \mathrm{~m}$ & $\mathrm{NP}+2.28$ & $\mathrm{TP}+0.87$ \\
\hline 满湖位 & $\mathrm{NP}+2.61$ & $\mathrm{TP}+1.20$ \\
\hline 海面上昇 0.44m & $\mathrm{NP}+3.05$ & $T \mathrm{TP}+1.64$ \\
\hline 海面上界 $0.88 \mathrm{~m}$ & $\mathrm{NP}+3.49$ & $\mathrm{TP}+2.08$ \\
\hline
\end{tabular}

計算に用いた設定潮位は，表 1 に示すように干潮 位 $(\mathrm{NP}+0.04 \mathrm{~m})$ と平均海面 $(\mathrm{NP}+1.40 \mathrm{~m})$, 満潮位 $(\mathrm{NP}+2.61 \mathrm{~m})$ の 3 種類で，それらの值に海面上昇によ る $0.44 \mathrm{~m}$ と $0.88 \mathrm{~m}$ をそれぞれ加えた合計 9 種類の潮 位を想定した.

また，本モデルの妥当性を検証するため，伊勢湾 台風来襲時と同じく潮位を $\mathrm{NP}+1.72 \mathrm{~m}$ に設定した計 算を行った. 湾奥の $\mathrm{E}$ 点における高潮潮位偏差, 実 測値の最大值（愛知県，1964）と計算值を比較する と，実測値と計算值がほぼ同じであることから，計 算による再現性が良好であるといえる（図 5)。

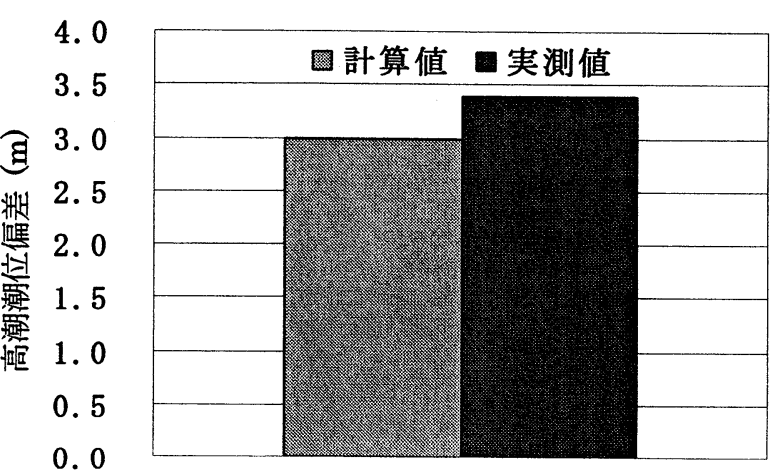

図 5 実測值と計算值の比較

\section{5. 計算結果}

\section{1 伊勢湾における高潮特性}

一般的に，湾奥は高潮に対して危険性が高いことが知られている．図 6 に示すように，伊勢湾の湾奥では （高潮）潮位偏差が最も大きくこの傾向と一致していた。

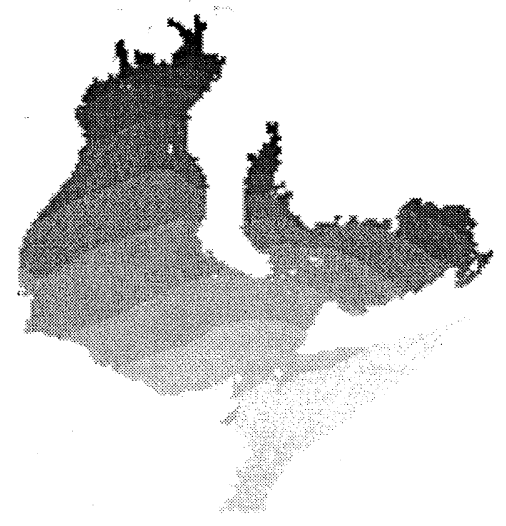

図 6 最高潮位偏差 （m）

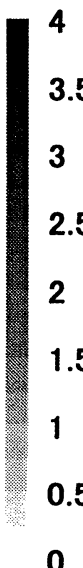

3.5

3

2.5

1.5

0.5

0

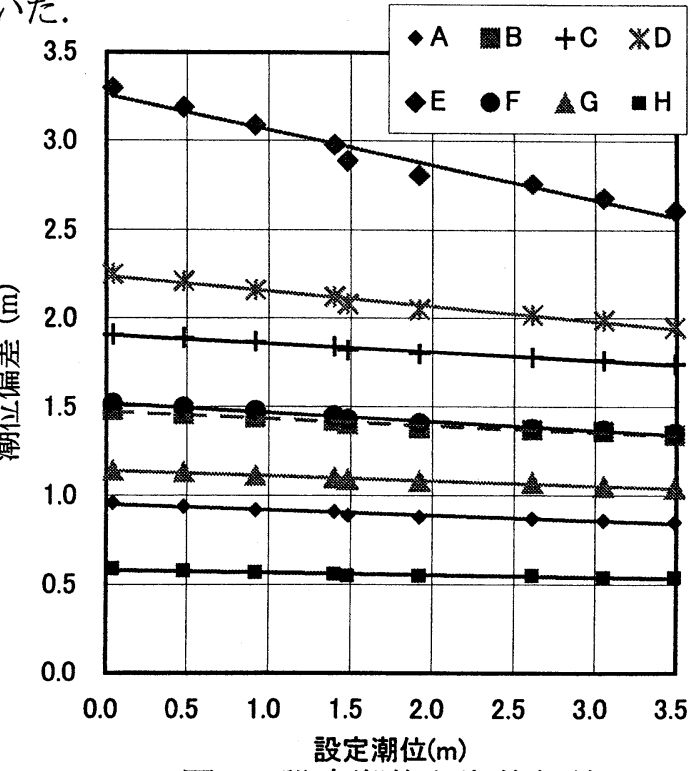

図 7 設定潮位と潮位偏差 


\section{2 海面上昇の高潮潮位偏差への影響}

設定潮位が大きくなると潮位偏差が一様に減少している（図 7）が，これは水深が大きくなると風による 吹き寄せ効果が減少するためと考えられる，吹き寄せ効果の減少によって最も大きな変化が生じたのは，湾 奥部であった. 湾奥 $\mathrm{E}$ 点では, 最高潮位における潮位偏差は最低潮位のそれと比べて $80 \mathrm{~cm}$ 小さくなってい る. すなわち, 海面上昇と潮位偏差の変化は相殺する方向で生じる.

\section{3 台風強大化の高潮潮位偏差への影響}

図 8 に示すように, 台風の最大到達強度 (MPI) が大きくなると潮位偏差の増大が顕著であり, 気圧の低下に よる水面の吸い上げ効果が現れている. また, 図 8 に示寸ように, 気圧深度 (MPI) が大きくなると, それに比 例して潮位偏差が上がる傾向が明確である.湾奥部にある $\mathrm{E}$ 点では, MPI を+10\%および $20 \%$ 大きくしたとき， 潮位偏差がそれぞれ $0.27 \mathrm{~m}, 0.54 \mathrm{~m}$ を高くなった. 各地点における潮位偏差の傾向もほぼ同じであり, 台風の MPI が増大すると, 潮位偏差もそれとほぼ同じ割合で増加することが分かった。

図 10 は $\mathrm{A}$ 点（湾の入口）と $\mathrm{E}$ 点（湾奥）の高潮潮位偏差の経時変化を示している. 台風通過時には, 両方 とも影響が大きくなり,湾奥の変化が激しい. 台風通過後及び接近時には影響は見られなかった. A 点と $\mathrm{E}$ 点 における潮位偏差のピークに着目すると， $\mathrm{E}$ 点におけるピークは $\mathrm{A}$ 点よりも時間的には遅れて現れているこ とが分かった。

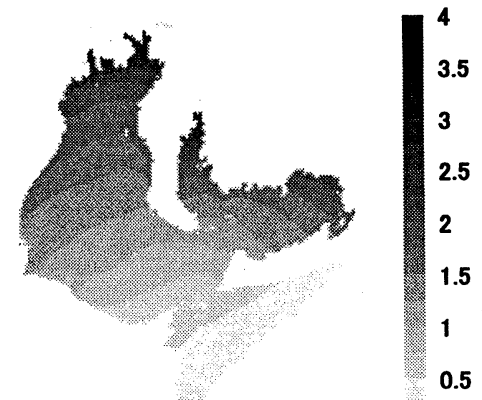

(m) 0

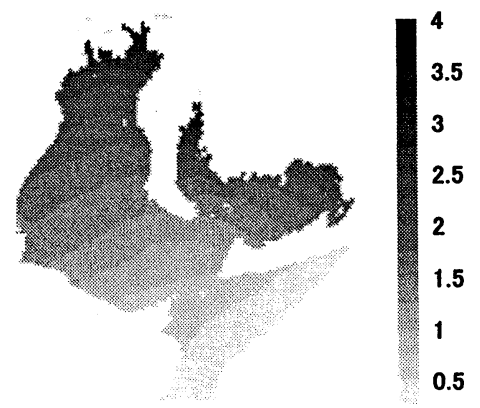

(m)

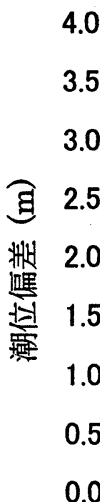

0.0

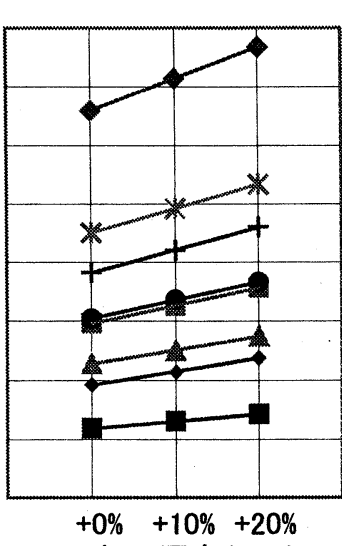

気压深度 (MPI)

図 8 MPI $+10 \%$ (右) $+20 \%$ (左)のときの最大潮位偏差分布

図 9 気圧変化と潮位偏差
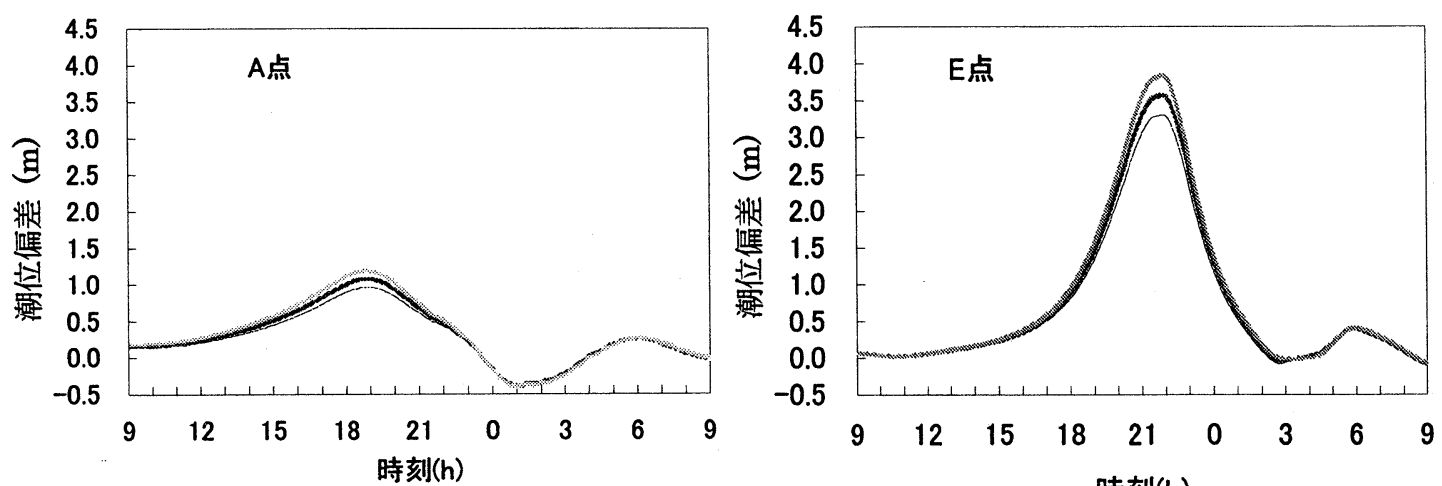

図 $10 \mathrm{~A}$ と E 地点潮位偏差の経時変化

（一伊勢湾台風，…… MPI $+10 \% 、$ MPI $+20 \%$ ）

\section{4 予測海水位の変化}

海面 $88 \mathrm{~cm}$ 上昇台風の MPI+20\%若慮し, 天文潮が満潮にあたる場合, 最高の海水位は T. P +5. 18m であり， これは伊勢湾台風の時の海水位を約 $1.5 \mathrm{~m}$ 上回る (図 11). 干潮時の予測海水位は図 12 に示寸. 図 11 と図 12

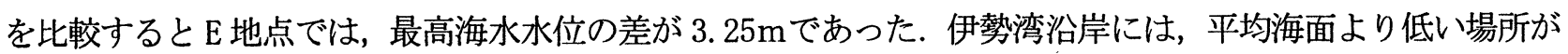
広く分布するため, 海面上昇が生じた状態で強大化した台風が来襲すると, 伊勢湾における高潮リスクは非 常に大きくなると考えられる. とりわけ，高潮の発生時間が満潮位時と重なるとリスクが大きくなることが 分かった. 


\section{6. 結論}

本研究で得られた結論は

以下のとおりである.

・設定潮位が大きくなると 風による吹き寄せ効果が 減少するため高潮潮位偏 差は減少する.このこと から，海面上昇と高潮潮 位偏差の変化は相殺する 方向で生じるといえる. ・台風が強大化すると,とり わけ湾奥で高潮潮位偏差 が大きくなる. その増大

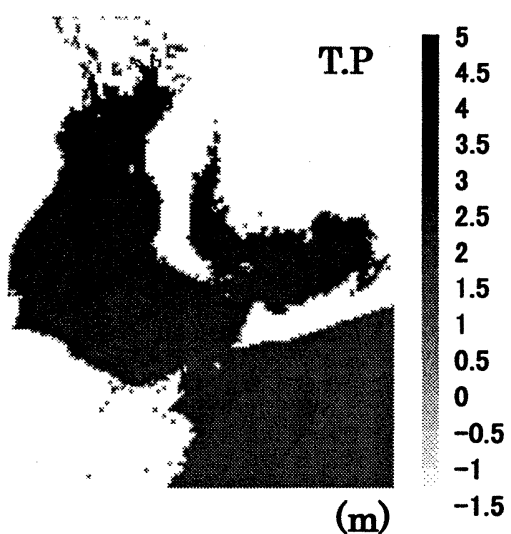

図 11 満潮位 $+0.88 \mathrm{~m}$ 海面上昇 + MPI が 20\%大きくした場合の海水位

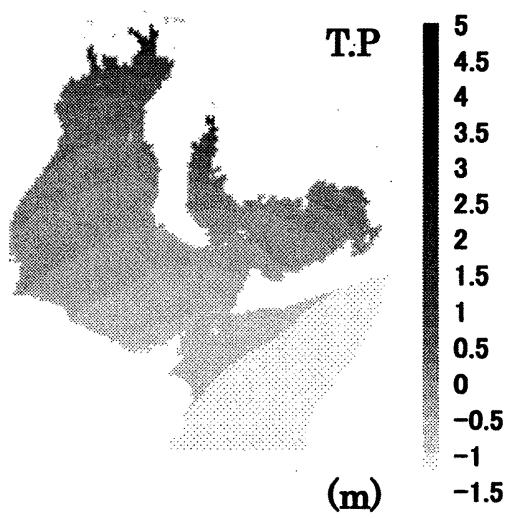

図 12 干潮時の海水位 率はMPI の増大とほぼ同 じであった。

・海面上昇 $0.88 \mathrm{~m}$ +台風の MPI

が 20\%増加した場合に, 伊勢湾の奥に, 最高海水位が T.P+5.18m となることが予測された。

今回の高潮計算では, 高潮の発生要因として，低気圧による吸い上げ効果と風の吹き寄せ効果のみを考慮 した.この他に，台風の移動に伴う強制波が湾水と共鳴を起こす” 台風の移動効果 “, 河川の洪水と高潮の 重なりの効果などが重要であろう。それらの要因と波浪の影響を考慮する高潮予測を行うことが今後の課題 である。それらの予測結果に基づいて，沿岸地域の高潮リスクをより現実的に予測することを目指したい。

謝辞 : 本研究では, 九州共立大学の小島治幸教授から提供された高潮計算プログラムに基づいて計算を行っ た.こころから感謝したい. また, 本研究は環境省地球環境研究総合推進費 (S-4)「温暖化の危険な水準及 び温室効果ガス安定化レベル検討のための温暖化影響の総合的評価に関する研究」による成果の一部である.

\section{参考文献}

愛知県 (1964)：伊勢湾台風災害復興誌，愛知県，pp43-49.

桐博英, 丹治肇, 中矢哲郎 (2004) : 地球温暖化後の台風に伴う高潮潮位偏差の変化, 海岸工学論文集, 第 51

巻, 土木学会, pp241-245.

小島治幸 (2001)：多層レベルモデルによる津波・高潮計算法プログラム，SURGE10B. FOR， 189p. 後藤智明, 小川由信 (1982) : Leap-frog 法を用いた津波の数值計算法, 東北大学土木工学科資料 68p. 土持章, 小島治幸 (2004) : 周防灘沿岸域における海面上昇による浸水ポテンシャルの推算, 海洋開発論文集,

第 20 巻, pp677-682.

筒井純一，磯部雅彦 (1992）：地球温暖化後の東京湾における高潮の予測，日本沿岸域会議論文集， No. 4 pp9-19.

IPCC WGI(2001) : Climate Change 2001, Scientific Basis, Cambridge University Press, 2001. 